\title{
First Detection of Rupestris stem pitting associated virus Particles by Antibody to a Recombinant Coat Protein
}

Natasa Petrovic, National Institute of Biology, Vecna pot 111, 1000 Ljubljana, Slovenia; Baozhong Meng, Department of Plant Pathology, Cornell University, New York State Agricultural Experiment Station, Geneva 144560462; Maja Ravnikar and Irena Mavric, National Institute of Biology, Vecna pot 111, 1000 Ljubljana, Slovenia; and Dennis Gonsalves, Department of Plant Pathology, Cornell University, New York State Agricultural Experiment Station, Geneva 14456-0462

\begin{abstract}
Petrovic, N., Meng, B., Ravnikar, M., Mavric, I., and Gonsalves, D. 2003. First detection of Rupestris stem pitting associated virus particles by antibody to a recombinant coat protein. Plant Dis. 87:510-514.

Rupestris stem pitting associated virus (RSPaV), a member of the genus Foveavirus, is associated with the Rupestris stem pitting component of the Rugose wood (RW) disease complex of grapevines. Heretofore, particles of RSPaV have not been visualized. In this work, flexuous rod particles approximately $723 \mathrm{~nm}$ in length were detected in the sap of infected grapevines by immunosorbent electron microscopy (ISEM), using a polyclonal antiserum produced to a recombinant coat protein of RSPaV. Particles of RSPaV were detected in tissue culture-, greenhouse-, and field-grown grapevines infected with RSPaV, but not in healthy control plants. Detection of virus particles by ISEM corresponded with detection of RSPaV by Western blot, enzyme-linked immunosorbent assay, and reverse transcription-polymerase chain reaction. Virus particles were decorated with the antibodies specific to RSPaV but not with antibodies to Grapevine virus A or Grapevine virus B, two other viruses believed to be associated with RW. This definitive identification of RSPaV particles will help define the etiology of RW.
\end{abstract}

Rupestris stem pitting (RSP), a component of the Rugose wood (RW) disease complex, is a widespread viral disease of grapevines $(3,6)$. Other viral diseases of the RW complex are LN 33 stem grooving (LNSG), Kober 5BB stem grooving, and grapevine corky bark (6). RSP is distinguished from the other components in that RSP does not induce symptoms on the indicators 'Cabernet Franc' (Vitis vinifera), 'LN 33' ('Couderc' $1613 \times$ 'Thompson Seedless'), or 'Kober 5BB' ( $V$. berlandieri $\times V$. riparia), but does develop stem pitting on the indicator $V$. rupestris 'St. George' within 2 to 3 years after graft-inoculation $(3,6)$. The etiology of RW diseases is not known, although indirect evidence suggests that Grapevine virus A (GVA) and Grapevine virus $B(\mathrm{GVB})$ are involved in RW (6).

In an effort to characterize the putative causal agent of RSP, a dsRNA associated with RSP (1) was cloned and sequenced, and shown to be of viral origin with a genome structure similar to Apple stem pitting virus (12). This was the first association of a viral sequence with RSP, and the

Corresponding author: Dennis Gonsalves E-mail: dgonsalves@pbarc.ars.usda.gov

Accepted for publication 11 October 2002.

Publication no. D-2003-0227-02R

(C) 2003 The American Phytopathological Society virus was named Rupestris stem pitting associated virus-1 (RSPaV-1) (12). The viral origin of RSP and the sequence of the dsRNA were concurrently confirmed by Zhang et al. (20), who named the virus Grapevine rupestris stem pitting associated virus. We designate the virus Rupestris stem pitting associated virus (RSPaV) in this study to avoid confusion. RSPaV is classified in the genus Foveavirus $(7,8)$. Comparative reverse transcription-polymerase chain reaction (RT-PCR) tests using $\mathrm{RSPaV}$-specific primers have shown that RSPaV is closely associated with RSP $(11,20)$. Furthermore, a family of sequence variants of $\mathrm{RSPaV}$ has been detected in RSP-infected grapevines (13).

Using the known RSPaV sequence, a polyclonal antiserum was produced to a recombinant coat protein $(\mathrm{CP})$ of $\mathrm{RSPaV}$ expressed in the bacterium Escherichia coli $(9,10)$. Serological tests (indirect enzyme-linked immunosorbent assay [ELISA] and Western blot) were compared to biological indicator indexing and RT-PCR assays, showing that the RT-PCR and serological tests could be used to diagnose RSP in grapevines more rapidly than by indicator indexing $(9,10,16,17)$. Minafra et al. (14) also produced an antiserum to a recombinant $\mathrm{CP}$ of RSPaV, which was used effectively to detect RSPaV by Western blot but not by ELISA.

Despite the recent characterization of the $\mathrm{RSPaV}$ genome, particles of RSPaV have not been identified. Long filamentous virus particles were observed in RSP-infected grapevines by electron microscopy (19). Monette and Godkin (15) observed filamentous particles in shoot tip-tissue cultured grapevine plants infected with RSP and LNSG. However, association of the particles with RSPaV could not be made because of the lack of $\mathrm{RSPaV}$-specific antiserum.

The availability of grapevine plants known to be infected with RSPaV, and availability of the RSPaV-specific antiserum (10), have provided us the necessary tools for visualizing and characterizing $\mathrm{RSPaV}$ particles by immunosorbent electron microscopy (ISEM). In this report, we show that flexuous rod particles ca. 723 $\mathrm{nm}$ long that react to the antiserum produced to the recombinant $\mathrm{CP}$ of $\mathrm{RSPaV}$ are detected consistently in RSP-infected grapevines.

\section{MATERIALS AND METHODS}

Plant materials. The grapevine accessions used as sources of RSPaV particles were Vitis vinifera and Vitis rupestris from Slovenia, Italy, France, and the United States. The origin and status of virus infection of the grapevine accessions used in the study are listed in Table 1 . The negative controls were plants of the grapevine indicator 'St. George' C1-2-12 and 'St. George' 239 that were derived from somatic embryo culture, tested free of $\mathrm{RSPaV}$ by Western blot, indirect ELISA, and RT-PCR (16).

Antisera. The polyclonal antiserum As7-276 was produced against a recombinant CP of RSPaV as described (10). The antiserum was effective in Western blot and indirect ELISA assays for detecting $\mathrm{RSPaV}$ in grapevines $(9,10,16,17)$. Antisera against GVB were provided by A. Rowhani (University of California, Davis), D. Goszczynski (South Africa), and A. Minafra (Bari, Italy). Antiserum against GVA was from Bioreba AG (Reinach, Switzerland).

RT-PCR. Double stranded RNA was isolated from stem tissue of green shoots, from whole plants or parts of tissuecultured plantlets, or from cambium of dormant canes of field-grown grapevines using the Qiagen RNeasy plant extraction kit according to the manufacturer's instructions (QIAGEN Inc., Valencia, CA). Cam- 
bium of dormant canes was used because most of the large-scale routine testing in sanitary selection of grapevine is performed using cambium of dormant grapevine material. Procedures for the RT-PCR assays were as described (11). Primer pairs 9 and 10 , and 13 and 14 were used as reported $(10,11)$. Primers 9 and 10 amplify a genomic segment from nucleotide (nt) positions 6244 to 6741 in open reading frame (ORF) 1 and ORF 2 (11). Primer pair 13 and 14 amplify a region at nt positions 4373 to 4711 in ORF 1 (11). Primers RSP48 and RSP49, obtained from A. Rowhani, targeted a region in the $\mathrm{CP}$ gene at $\mathrm{nt}$ positions 8178 to 8507 (RSP48: 5'-AGGCTGGGATTATAAGGGAGGT-3'; RSP49: 5'-CCAGCCGTTCCACCACTAAT$\left.3^{\prime}\right)$.

Western blot and indirect ELISA. The Western blot and indirect ELISA assays were done as described (10) using the polyclonal antiserum As7-276 produced against the recombinant $\mathrm{CP}$ of $\mathrm{RSPaV}$.

Electron microscopy (EM) and virus particle measurements. The following plant material was used in EM: fresh leaves, stems, and roots of plantlets after 6 to 8 weeks of growth in tissue culture as axillary shoots; fresh leaves and stems of green shoots from 20-year-old field-grown plants, collected between May and August, or fresh cambium tissue of dormant canes collected from same plants in winter (between December and February); fresh leaves and stems of 1-year-old greenhousegrown plants. Small amounts of tissue (about $20 \mathrm{mg}$ ) were macerated in extraction buffer ( $0.1 \mathrm{M}$ phosphate, $\mathrm{pH} 7.2$, containing $2 \%$ polyvinylpyrrolidone [PVP]40 ) in the 1:10 ratio, and used for incubation on EM grids. In some samples, we compared the above described extraction buffer with the same extraction buffer without the PVP, to test its importance for the stability of virus particles. To test the stability of virus particles in plant extracts frozen at $-20^{\circ} \mathrm{C}$, we also used frozen extracts from stems and leaves of some of the above described field-grown plants. To prepare EM samples for negative contrast without using As7-276, carbon-coated Formvar grids were coated with about 10 $\mu \mathrm{l}$ of plant extract for $1 \mathrm{~h}$. After incubation, each grid was rinsed with double-distilled water and stained by streaming the grid with a few drops of $1 \%$ uranyl acetate. To prepare samples for ISEM, $10 \mu \mathrm{l}$ of crude antiserum As7-276 (diluted 1:1,000 vol/vol with phosphate buffer) was added to the carbon-coated Formvar grids, incubated for $5 \mathrm{~min}$, and rinsed with phosphate buffer ( $\mathrm{pH}$ 7.2). Each grid was then incubated with $10 \mu \mathrm{l}$ of plant extract to trap $\mathrm{RSPaV}$ particles. Different incubation times were used for plant extracts to find the optimal conditions: 1 and $2 \mathrm{~h}$ at room temperature, and overnight at $4^{\circ} \mathrm{C}$. After incubation with plant extracts, grids were rinsed with double-distilled water, followed by staining with $1 \%$ uranyl acetate as described above. Decoration is a procedure used to identify a virus by coating of virus particles with specific antibodies. If there is a specific relationship between the virus and the antibodies, a halo of IgG molecules will readily visualized by EM after negative staining. To decorate, each grid containing trapped virus particles was incubated with the antiserum As7-276 (diluted 1:50) for $15 \mathrm{~min}$, rinsed, and stained as described above. Each grid was then rinsed with double-distilled water and stained as described above. Grids were viewed with a Philips CM-100 transmission electron microscope (Eindhoven, Holland). The length of 104 particles was measured on the grids prepared for ISEM without decoration using plant extract of stem samples from tissue cultured plantlets of 'Pinot Noir' 115 infected with RSPaV. Negative controls were 'St. George' 239 and 'St. George' C1-2-12.

\section{RESULTS}

Identification of RSPaV particles by ISEM using As7-276. Symptoms of RW were observed on plants of $V$. vinifera 'Refosk' $38 \mathrm{VIII} / 44$ and 'Refosk' $20 \mathrm{~V} / 4$, but not on 'Refosk' 18 II/6 or the 'St. George' vines. Clones of 'Taminga' $3 \mathrm{c}$ and 'Pinot Noir' 3d induced typical stem pitting symptoms on graft-inoculated 'St. George' indicators.

Initial trials to detect $\mathrm{RSPaV}$ particles by ISEM were done with tissue-cultured plants of RSPaV-infected 'Pinot Noir' 115, which was heavily infected with RSPaV as tested by Western blot, ELISA, and RTPCR (Table 2). Efforts to observe RSPaV particles without trapping with the antiserum were not successful. However, virus particles were observed when grids were coated with the antiserum As7-276 prior to applying plant extract. The concentrations of virus particles were very low, with about 10 particles observed per grid square at $\times 34,000$ magnification. Nonetheless, specificity of the virus particles to $\mathrm{RSPaV}$ was form around the virus particles that can be

demonstrated by the decoration of virus particles with the antiserum to recombinant $\mathrm{CP}$ of RSPaV (Fig. 1, bottom panel). Virus particles were not detected in plants of 'St. George' 239, which had tested negative for RSPaV by Western blot, ELISA, and RTPCR (Table 2).

The virus particles observed by ISEM were flexuous rods with a normal length of $723 \mathrm{~nm}$, which is in the range of other foveaviruses (7). The particles showed a normal distribution in length, with the majority (57 of 104 measured) falling in the 600 to $799 \mathrm{~nm}$ range (Fig. 2). The normal length of the particles was calculated as the mean of the 57 particles. Thirteen of the measured particles were longer than $1,000 \mathrm{~nm}$, which may have resulted from end-to-end aggregations of virus particles. All of the particles observed were decorated by the RSPaV-specific antiserum by ISEM.

Cross-reactions of particles of RSPaV with antisera to other viruses. Plants of $V$. vinifera 'Refosk' 38 VIII/44 showed RW symptoms and tested positive for RSPaV, but tested negative for GVB, GVA, and other viruses such as Grapevine fleck virus, Grapevine leafroll associated virus-1, -2, -3, and -6, Arabis mosaic virus, and Grapevine fanleaf virus by extensive double antibody sandwich-ELISA. Furthermore, these plants tested negative for GVA and GVB by RT-PCR (data not shown).

To test possible cross-reactions of $\mathrm{RSPaV}$ particles with antisera produced against GVA and GVB, virus particles in tissue extracts of 'Refosk' 38 VIII/44 were trapped with antiserum As7-276 and visualized by ISEM without decoration, or after decoration with antiserum to GVB, GVA, or RSPaV. Flexuous rod particles $723 \mathrm{~nm}$ long were observed in all ISEM preparations that were trapped by As7-276; the virus particles were only decorated by As7-276 (Fig. 1) but not by antiserum to GVA or GVB (Table 3).

Correlation of RSPaV particles observed by ISEM with detection of RSPaV by RT-PCR, Western blot, and

Table 1. Virus status of grapevines used for detection of Rupestris stem pitting associated virus $(\mathrm{RSPaV})$ particle

\begin{tabular}{lll}
\hline Grapevine accession & Origin & Viruses detected $^{\mathbf{a}}$ \\
\hline 'Refosk' 38 VIII/44 (Vitis vinifera) & Slovenia & $\mathrm{RSPaV}$ \\
'Refosk' 20 V/4 $($ V. vinifera $)$ & Slovenia & $\mathrm{RSPaV}, \mathrm{GFkV}$ \\
'Refosk' 18 II/6 $($ V. vinifera $)$ & Slovenia & $\mathrm{RSPaV}$ \\
'Taminga' 3c $($ V. vinifera $)$ & Australia & $\mathrm{RSPaV,} \mathrm{GLRaV-3,} \mathrm{GVB}$ \\
'Pinot Noir' 3d $($ V. vinifera $)$ & Italy & $\mathrm{GVB}, \mathrm{RSPaV}$ \\
'Pinot Noir' 115 $($ V. vinifera $)$ & France & $\mathrm{RSPaV}$ \\
'St. George' Cl-2-3 $($ V. rupestris $)$ & United States & $\mathrm{RSPaV}$ \\
'St. George' Cl-2-12 $(\text { V. rupestris })^{\mathrm{b}}$ & United States & None \\
'St. George' 239 $(\text { V. rupestris })^{\mathrm{b}}$ & United States & None \\
\hline
\end{tabular}

a Grapevines were tested for Grapevine fanleaf virus, Grapevine leafroll associated virus (GLRaV)1, -2, and -3, Grapevine virus A (GVA), Grapevine virus B (GVB), and Grapevine fleck virus $(\mathrm{GFkV})$ by one or more diagnostic tests of enzyme-linked immunosorbent assay, Western blot, reverse transcription-polymerase chain reaction (RT-PCR), and indicator indexing on Vitis rupestris 'St. George' $(6,10)$.

b $V$. rupestris 'St. George' Cl-2-12 and 'St. George' 239 were used as negative controls because $\mathrm{RSPaV}$ was not detected in these plants by any of the laboratory methods available. 
indirect ELISA. To compare the detection of RSPaV by ISEM with the other assays, tissue extracts from each of nine tissue culture- or greenhouse-grown plants were tested by RT-PCR, Western blot, indirect ELISA, and ISEM. The results showed a perfect correlation between detection of RSPaV particles by ISEM and detection of the virus by RT-PCR, Western blot, and ELISA (Table 2). RSPaV was detected using all four assays from extracts of stems, leaves, and roots of tissue-cultured plantlets sampled throughout the year. Similar results were obtained with extracts from cambium samples of young shoots of greenhouse plants throughout the year, except for 'Refosk' 18 II/6 that tested negative for RSPaV by indirect ELISA. The extract of 'Refosk' 18 II/6 had an ELISA reading of 0.57 , which is below the positive threshold (Table 2).

Limited tests also showed that RSPaV particles were detected by ISEM in fieldgrown plants of 'Refosk' $38 \mathrm{VII} / 44$. The $\mathrm{RSPaV}$ particles were detected in stem samples of green shoots and in young leaves, but not in old leaves collected from the same shoot, regardless of whether samples were assayed in spring or early summer. Particles of RSPaV were observed by ISEM in cambium tissue of dormant canes of RSPaV-infected $V$. vinifera 'Pinot Noir' 3d. However, particles of RSPaV were not detected in the cambium tissue of dormant canes of RSPaV-infected $V$. rupestris 'St. George' Cl-2-3, although virus particles were observed in green shoot samples from the same plant. Both vines were assayed in March, toward the end of the dormant season.

The number of particles of RSPaV observed by ISEM was low. The highest number of virus particles was observed in preparations made from young tissues (stems of green shoots, gathered from greenhouse-grown plants or field-grown grapevines in early summer), and in all organs of tissue cultured plantlets. At a magnification of $\times 34,000$, two to 10 particles were observed per grid square.
Factors influencing detection of RSPaV particles in plants. Different incubation times and conditions for trapping $\mathrm{RSPaV}$ particles in ISEM from plant extracts of 'Refosk' 38 VII/44 were tested. At room temperature, $\mathrm{RSPaV}$ particles incubated for $1 \mathrm{~h}$ were more stable than particles incubated for $2 \mathrm{~h}$ when virus particles tend to break down. Overnight incubation at $4^{\circ} \mathrm{C}$ had a similar effect to incubation at room temperature for $2 \mathrm{~h}$. Virus particles were not observed in extracts of 'Refosk' 38 VIII/44 frozen at $-20^{\circ} \mathrm{C}$. These results indicate that shorter incubation times such as $1 \mathrm{~h}$ and immediate use of extracted plant sap are critical for detecting RSPaV by ISEM.

Our observations suggested that presence of PVP in the buffer was important for detection of RSPaV particles by ISEM. Particles were not observed in plant extracts prepared with buffer that did not contain PVP.

\section{DISCUSSION}

Results of this study demonstrated, for the first time, that particles of RSPaV are
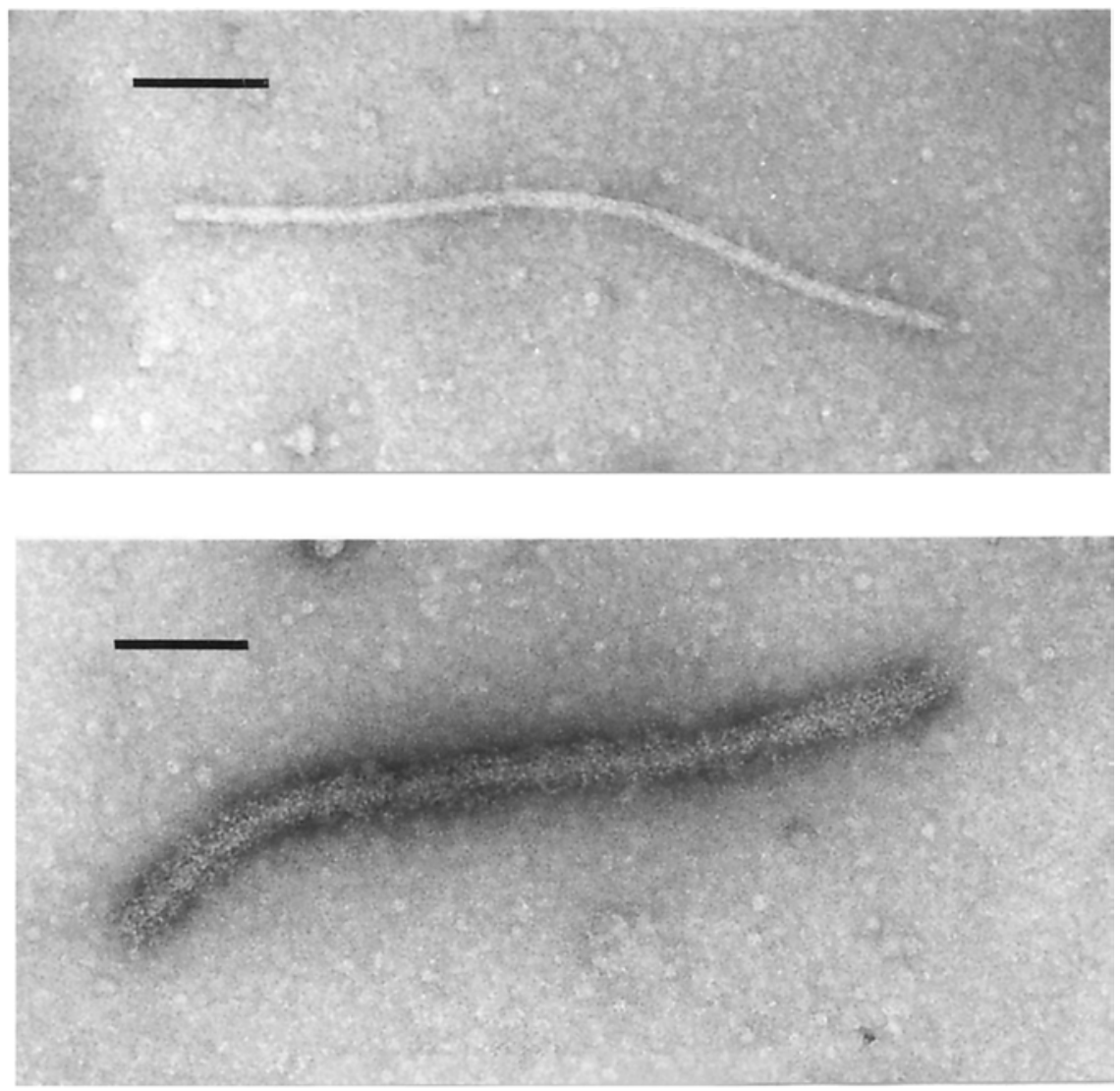

Fig. 1. Detection of Rupestris stem pitting associated virus (RSPaV) particles by immunosorbent electron microscopy. Nondecorated (top panel) and decorated (bottom panel) particles were trapped with the polyclonal antiserum As7-276 produced to the recombinant coat protein of RSPaV (10). Bar represents $100 \mathrm{~nm}$.

Table 2. Correlation of detection of Rupestris stem pitting associated virus (RSPaV) by ISEM with detection by ELISA, Western blot, and RT-PCR ${ }^{\mathrm{a}}$

\begin{tabular}{|c|c|c|c|c|c|c|c|c|c|c|}
\hline \multirow{3}{*}{$\frac{\text { Grapevine accessions }}{\text { 'Pinot Noir' } 115 \text { (Vitis vinifera) }}$} & \multicolumn{2}{|c|}{ ISEM } & \multicolumn{2}{|c|}{ Western blot } & \multicolumn{4}{|c|}{ ELISA } & \multicolumn{2}{|c|}{ RT-PCR } \\
\hline & \multirow{2}{*}{$\frac{\mathbf{T C}^{\mathbf{b}}}{+^{\mathrm{d}}}$} & \multirow{2}{*}{$\frac{\mathbf{G H}^{\mathbf{c}}}{+}$} & \multirow{2}{*}{$\frac{\text { TC }}{+}$} & \multirow{2}{*}{$\frac{\text { GH }}{+}$} & \multicolumn{2}{|c|}{$\mathbf{T C}$} & \multicolumn{2}{|c|}{ GH } & \multirow{2}{*}{$\frac{\mathbf{T C}}{+}$} & \multirow{2}{*}{$\frac{\text { GH }}{+}$} \\
\hline & & & & & 1.33 & + & 0.99 & + & & \\
\hline 'Refosk' 38 VIII/44 (V. vinifera) & + & + & + & + & 0.83 & + & 0.81 & + & + & + \\
\hline 'Refosk' 20 V/4 (V. vinifera) & NT & + & NT & + & 0.78 & + & 0.79 & + & + & + \\
\hline 'Taminga' $3 \mathrm{c}(V$. vinifera $)$ & NT & + & + & + & 1.01 & + & 0.95 & + & + & + \\
\hline 'Pinot Noir' 3d (V. vinifera) & NT & + & + & + & 1.02 & + & 0.89 & + & + & + \\
\hline 'St. George' Cl-2-3 (V. rupestris) & NT & + & + & + & 0.85 & + & 0.69 & + & + & + \\
\hline 'Refosk' 18 II/6 (V. vinifera) & NT & + & + & + & 0.84 & + & 0.57 & - & + & + \\
\hline 'St. George' 239 (V. rupestris) & - & - & - & - & 0.26 & - & 0.34 & - & - & - \\
\hline 'St. George' Cl-2-12 (V. rupestris) & - & - & - & - & 0.35 & - & 0.31 & - & - & - \\
\hline
\end{tabular}

a ISEM = immunosorbent electron microscopy; ELISA = enzyme-linked immunosorbent assay (11); RT-PCR = reverse transcription-polymerase chain reaction (11). The threshold for a positive reaction by ELISA was set at two times the highest OD 405 value of the negative control samples of 'St. George' 239 and 'St. George' C1-2-12. The antiserum used (As7-276) was produced against a recombinant coat protein of RSPaV (10).

b $\mathrm{TC}=$ tissue cultured plantlets assayed.

c $\mathrm{GH}=$ greenhouse-grown plants.

${ }^{\mathrm{d}}+=$ positive $;-=$ negative $;$ and $\mathrm{NT}=$ not tested . 
flexuous rods with a mean length of ca. $723 \mathrm{~nm}$. This conclusion is based on evidence that the virus particles observed were decorated with antiserum to a recombinant $\mathrm{CP}$ of RSPaV. In addition, the grapevines also tested positive for $\mathrm{RSPaV}$ by Western blot and ELISA using the RSPaV-specific antiserum $(10,16,17)$, and by RT-PCR using primers specific for RSPaV. Filamentous particles of similar size and shape were previously observed by electron microscopy of extracts of cambium samples from stem tissue of grapevines infected with RSP, as determined by biological indexing on $V$. rupestris 'St. George' $(15,19)$. However, these particles could not be identified as RSPaV because specific antiserum to RSPaV was not available when those experiments were conducted.

Trapping RSPaV particles on antiserumcoated grids in the ISEM procedure was essential to visualize the virus particles, suggesting that the virus occurs in the host at very low concentrations, or that the virus particles are unstable and break down readily unless immobilized rapidly on the grid. The former is more likely, as very few particles were observed on each grid, even after trapping with the antiserum As7-276. Attempts by others to visualize particles of $\mathrm{RSPaV}$ suggest that RSPaV particles are present in grapevines in low concentrations $(15,19)$. This may explain the inability to visualize the virus particles in most of the grapevines tested.

Despite the apparent low concentrations of virus particles in grapevines, the antiserum used in this study allowed for consistent detection of RSPaV particles in different plant parts of a variety of grapevine genotypes growing in different environments (greenhouse, tissue culture, and fields). However, several factors need to be controlled for consistent results. Trapping of virus particles with $\mathrm{RSPaV}$-specific antiserum was essential to visualize the virus particles. RSPaV particles tend to be unstable in the sap of all plant tissues examined. Limiting the incubation time to 1 $\mathrm{h}$ for trapping virus particles, using freshly prepared plant extracts prepared in phosphate buffer containing PVP, and selecting young shoots or tissue cultured plants are recommended to optimize detection of intact particles of $\mathrm{RSPaV}$ by ISEM. In a concurrent report (10), we showed that ELISAs of leaves of actively growing plants were more successful than assays of old leaves. This supports the observation of this study that samples collected early in the summer were a better source of plant tissue for visualizing particles of $\mathrm{RSPaV}$ by ISEM than plant samples collected toward the end of the growing season.

Minafra et al. (14) recently produced an antiserum to a recombinant $\mathrm{CP}$ of an $\mathrm{RSPaV}$ isolate (20). Although effective at detecting $\mathrm{RSPaV}$ by Western blot, that antiserum was unable to detect RSPaV by
ELISA. In contrast, the antiserum As7-276 was used successfully to detect RSPaV by ISEM, Western blot, and indirect ELISA (10). It would be interesting to compare effectiveness of the two antisera for detecting RSPaV particles by ISEM.

Recombinant CPs have been especially valuable as a source of antigen for producing antibodies against viruses (10) that are impossible or difficult to purify. This is true for many viruses infecting grapevines, for which herbaceous hosts have not been identified. Interestingly, As7-276 was not effective for detecting RSPaV by immunocapture-RT-PCR (N. Petrovic, unpublished data), unlike some other antibodies pro- duced against recombinant viral CPs $(4,5)$. Results of this ISEM study suggest that inability to detect a virus may reflect instability of the virus particles combined with low virus concentrations rather than inherent properties of the antibodies.

Results of this and other studies $(12,20)$ will enable clarification of the molecular and physical characteristics of RSPaV. Available evidence suggests that RSPaV is the causal agent of RSP $(10-12,18,20)$. However, additional evidence implies that $\mathrm{RSPaV}$ alone is not the cause of RW symptoms observed in numerous $V$. vinifera grapevines (2). Bonfigioli et al. (2) suggested that combination of GVA and

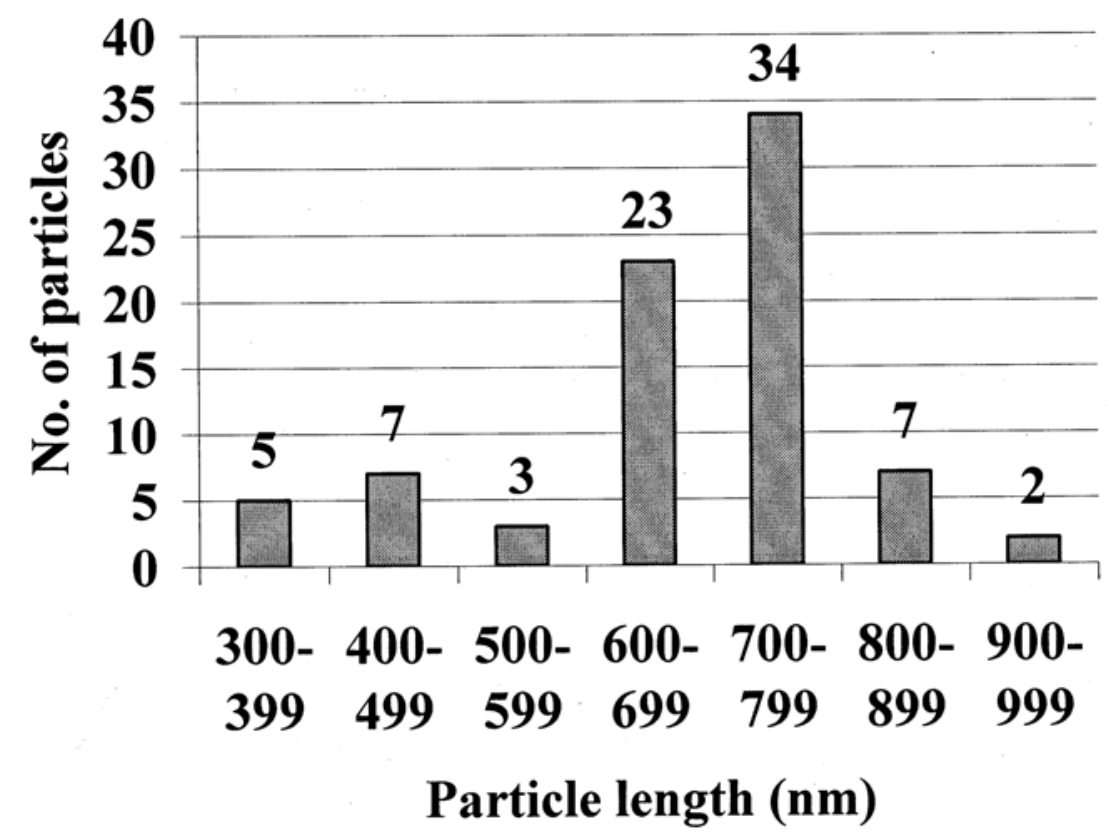

Fig. 2. Histogram of the particle lengths of Rupestris stem pitting associated virus. The grapevine accession used was Vitis vinifera 'Pinot Noir' 115 . Numbers above each bar indicate number of particles whose length fall into the range designated below each bar.

Table 3. Immunosorbent electron microscopy analysis of the serological relatedness of Rupestris stem pitting associated virus (RSPaV) particles to antisera against Grapevine virus A (GVA) and Grapevine virus $B(\mathrm{GVB})^{\mathrm{a}}$

\begin{tabular}{|c|c|c|c|}
\hline \multicolumn{2}{|c|}{ Antisera used to ${ }^{b}$} & \multicolumn{2}{|c|}{ Detection of RSPaV particles ${ }^{c}$} \\
\hline Trap & Decorate & Nondecorated & Decorated \\
\hline \multicolumn{4}{|c|}{ 'Refosk' 38 VII/44 (infected with RSPaV) } \\
\hline As7-276 ${ }^{\mathrm{d}}$ & As7-276 & $+^{\mathrm{d}}$ & + \\
\hline As7-276 & GVB (Goszczynski)e & + & - \\
\hline As7-276 & GVB (Minafra) ${ }^{\mathrm{e}}$ & + & - \\
\hline As7-276 & GVB (Rowhani) ${ }^{\mathrm{e}}$ & + & - \\
\hline As7-276 & GVA (Bioreba) ${ }^{\mathrm{e}}$ & + & - \\
\hline \multicolumn{4}{|c|}{ 'St. George' (free of RSPaV) } \\
\hline Same treatr & & - & - \\
\hline
\end{tabular}

a Virus particles of RSPaV from grapevine extracts were trapped with crude antiserum As7-276, rinsed with double-distilled water, stained, and observed with a Philips CM-100 transmission electron microscope. Each treatment was repeated at least once.

b "Trap" refers to the enrichment of virus particles through affinity to specific antibodies, resulting in collection of more virus particles by the grid.

c "Decorate" refers to the coating of virus particles with specific antibodies, producing a halo of IgG molecules around the virus particles that can be readily visualized by electron microscopy after negative staining.

$\mathrm{d}$ The antiserum As7-276 was a polyclonal antiserum produced against a recombinant coat protein of RSPaV (10).

e Sources of antisera to other viruses are indicated in parentheses. 
$\mathrm{RSPaV}$ might induce stem pitting. Visualization of virus particles by specific antibodies provides another tool to investigate the relationship between $\mathrm{RSPaV}$ and the RW disease complex. However, critical proof of the role of these viruses in the RW complex will come through inoculation of grapevines with pure cultures of these viruses alone and in combinations.

\section{LITERATURE CITED}

1. Azzam, O. I., Gonsalves, D., and Golino, D. A. 1991. Detection of dsRNA in grapevines showing symptoms of rupestris stem pitting disease and the variabilities encountered. Plant Dis. 75:960-964.

2. Bonfigioli, R. G., Habili, N., Green, M., Schliefert, L. F., and Symons, R. H. 1998. The hidden problem - Rugose wood associated viruses in Australian viticulture. Austral. Grapegr. Winemaker 9-13.

3. Goheen, A. C. 1988. Rupestris stem pitting. Page 53 in: Compendium of Grape Diseases. R. C. Pearson and A. C. Goheen, eds. American Phytopathological Society, St. Paul, MN.

4. Jelkmann, W., and Keim-Konrad, R. 1997. Immuno-capture polymerase chain reaction and plate-trapped ELISA for the detection of apple stem pitting virus. J. Phytopathol. $145: 499-503$.

5. Ling, K. S., Zhu, H. Y., Petrovic, N., and Gonsalves, D. 2001. Comparative effectiveness of ELISA and RT-PCR for detecting grapevine leafroll associated closterovirus-3 in field collected samples. Am. J. Enol. Vitic. 52:21-27.

6. Martelli, G. P. 1993. Rugose wood complex. Pages 45-54 in: Graft-transmissible diseases of grapevines: Handbook for detection and diagnosis. G. P. Martelli, ed. Food and Agriculture Organization of the United Nations, Rome.

7. Martelli, G. P., and Jelkmann, W. 1998. Foveavirus, a new plant virus genus. Arch. Virol. 143:1245-1249.

8. Martelli, G. P., and Jelkmann, W. 2000. Genus Foveavirus. Pages 985-989 in: Virus Taxonomy. Seventh Report of the International Committee on Taxonomy of Viruses, Virology Division, International Union of Microbiological Societies, M. H. V. Van Regenmortel, et al., eds. Academic Press, New York.

9. Meng, B., Credi, R., Petrovic, N., and Gonsalves, D. 2000. Serological detection of $\mathrm{RSPaV}$ in grapes as compared to RT-PCR and indicator indexing. Pages 131-132 in: Proc. Meeting Int. Council Study Viruses Virus-like Dis. Grapevine, 13th. Adelaide, South Australia.

10. Meng, B., Credi, R., Petrovic, N., Tomazic, I., and Gonsalves, D. 2003. Antiserum to recombinant virus coat protein detects Rupestris stem pitting associated virus in grapevines. Plant Dis. 87:515-522.

11. Meng, B. Z., Johnson, R., Peressini, S., Forsline, P. L., and Gonsalves, D. 1999. Rupestris stem pitting associated virus-1 is consistently detected in grapevines infected with rupestris stem pitting. Eur. J. Plant Pathol. 105:191199.

12. Meng, B. Z., Pang, S. Z., Forsline, P. L., McFerson, J. R., and Gonsalves, D. 1998. Nucleotide sequence and genome structure of grapevine Rupestris stem pitting associated virus-1 reveal similarities to apple stem pitting virus. J. Gen. Virol. 79:2059-2069.

13. Meng, B. Z., Zhu, H. Y., and Gonsalves, D. 1999. Rupestris stem pitting associated virus-
1 consists of a family of sequence variants. Arch. Virol. 144:2071-2085.

14. Minafra, A., Casati, P., Elicio, V., Rowhani, A., Saldarelli, P., Savino, V., and Martelli, G. P. 2000. Serological detection of Grapevine rupestris stem pitting-associated virus (GRSPaV) by a polyclonal antiserum to recombinant virus coat protein. Vitis 39:115-118.

15. Monette, P. L., and Godkin, S. E. 1995. Detection of capillovirus-like particles in a grapevine affected with rugose wood. Vitis 34:241-242.

16. Petrovic, N., Penev, B., Krastanova, T., Meng, B., and Gonsalves, D. 2000. Distribution of Rupestris stem pitting associated virus in greenhouse and field grown Vitis rupestris cv. 'Saint George'. Pages 35-36 in: Proc. Meeting Int. Council Study Viruses Virus-like Dis. Grapevine, 13th. Adelaide, South Australia

17. Petrovic, N., Soster, P., Korosec-Koruza, Z Ravnikar, M., Meng, B., and Gonsalves, D. 2000. First results on the use of laboratory methods for detection of Rupestris stem pitting associated virus-1 in grapevines in Slovenia. Page 137 in: Proc. Meeting Int. Council Study Viruses Virus-like Dis. Grapevine, 13th. Adelaide, South Australia.

18. Steward, S., and Nassuth, A. 2001. RT-PCR based detection of Rupestris stem pitting associated virus within field-grown grapevines throughout the year. Plant Dis. 85:617-620.

19. Tzeng, H. L., Tzeng, D. D., and Goheen, A. C. 1993. Anatomical and tissue culture studies of rupestris stem pitting-affected grapevines. Bot. Bull. Acad. Sinica (Taipei) 34:73-82

20. Zhang, Y.-P., Uyemoto, J. K., Golino, D. A., and Rowhani, A. 1998. Nucleotide sequence and RT-PCR detection of a virus associated with grapevine rupestris stem-pitting disease. Phytopathology 88:1231-1237. 